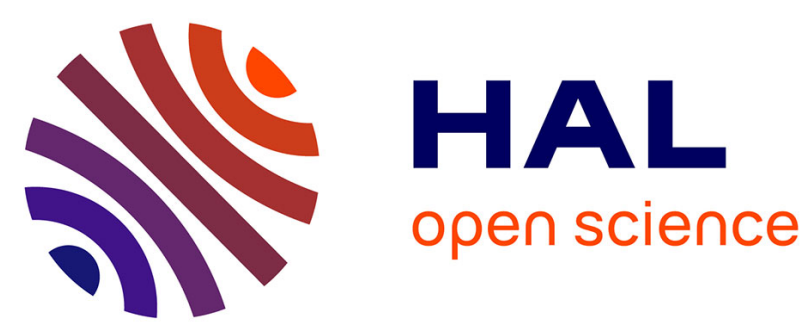

\title{
Synthesis, Photophysical Properties, and Living Cell Imaging of Theranostic Half-Sandwich Iridium-4,4-Difluoro-4-bora-3a,4a-diaza-s-indacene (BODIPY) Dyads
}

Jeremy M. Zimbron, Kévin Passador, Blaise Gatin-Fraudet, Claude-Marie

Bachelet, Damian Plazuk, Lise-Marie Chamoreau, Candice Botuha, Serge

Thorimbert, Michèle Salmain

\section{To cite this version:}

Jeremy M. Zimbron, Kévin Passador, Blaise Gatin-Fraudet, Claude-Marie Bachelet, Damian Plazuk, et al.. Synthesis, Photophysical Properties, and Living Cell Imaging of Theranostic Half-Sandwich Iridium-4,4-Difluoro-4-bora-3a,4a-diaza-s-indacene (BODIPY) Dyads. Organometallics, 2017, 36 (18), pp.3435-3442. 10.1021/acs.organomet.7b00250 . hal-01537852

HAL Id: hal-01537852

https://hal.sorbonne-universite.fr/hal-01537852

Submitted on 15 Jun 2017

HAL is a multi-disciplinary open access archive for the deposit and dissemination of scientific research documents, whether they are published or not. The documents may come from teaching and research institutions in France or abroad, or from public or private research centers.
L'archive ouverte pluridisciplinaire HAL, est destinée au dépôt et à la diffusion de documents scientifiques de niveau recherche, publiés ou non, émanant des établissements d'enseignement et de recherche français ou étrangers, des laboratoires publics ou privés. 


\title{
Synthesis, photophysical properties and living cell imaging of theranostic half-sandwich iridium -4,4-Difluoro-4-bora-3a,4a- diaza-s-indacene (BODIPY) Dyads
}

\author{
Jeremy M. Zimbron, ${ }^{\mathrm{a},{ }^{\dagger}}$ Kévin Passador, ${ }^{\mathrm{a},}{ }^{\dagger}$ Blaise Gatin-Fraudet, ${ }^{\mathrm{a}}$ Claude-Marie Bachelet, ${ }^{\mathrm{b}}$ Damian \\ Plazuk, ${ }^{\mathrm{c}}$ Lise-Marie Chamoreau, ${ }^{\mathrm{a}}$ Candice Botuha, ${ }^{\mathrm{a}}$ Serge Thorimbert, ${ }^{{ }^{*}}$ Michèle Salmain ${ }^{\mathrm{a}}$. \\ a Sorbonne Universités, UPMC Univ Paris 06, CNRS, Institut Parisien de Chimie Moléculaire (IPCM), 4 place Jussieu, \\ 75005 Paris, France; ${ }^{b}$ Plateforme d'Imagerie Cellulaire, Pitié-Salpêtrière, Inserm U 1127, CNRS UMR 7225, Sorbonne \\ Universités, UPMC Université Paris 06 UMRS 1127, 75013 Paris, France; ${ }^{\mathrm{c}}$ Department of Organic Chemistry, Faculty of \\ Chemistry, University of Lodz, Tamka 12, 91-403 Lodz, Poland.
}

${ }^{\dagger}$ Authors contributed equally to this work

\begin{abstract}
We report the synthesis, characterization and photophysical properties of two new cyclometalated half-sandwich iridium (III) complexes having the general formula $\left[\left(\eta^{5}-\mathrm{Cp} *\right) \operatorname{Ir}(\mathrm{ppy}) \mathrm{Z}\right] \mathrm{PF}_{6}$ where $\eta^{5}-\mathrm{Cp} \mathrm{p}^{*}=$ pentamethylcyclopentadienyl, ppy $=2-$ phenyl-pyridine as $\mathrm{C}^{\wedge} \mathrm{N}$-chelating ligand and $\mathrm{Z}=3$ - or 4-pyridyl-BODIPY (BODIPY = 4,4-difluoro-4-bora-3a,4a-diaza-s-indacene dye containing a 3- or 4-pyridyl group at the meso position). The molecular structure of both complexes has been determined by $\mathrm{X}$ ray crystallography. The photophysical properties of the dyads were investigated and compared to the pyridiyl-BODIPY precursors. Antiproliferative studies demonstrated that one of the compounds was highly active with submicromolar $\mathrm{IC}_{50}$ on a panel of cancer cell lines. The replacement of the chlorido ligand by the pyridyl-BODIPY increased the lipophilicity of the complexes and slowed down the hydrolysis rate, which in turn increased the cytotoxicity of the metallodrug candidates. For the first time, cell uptake of one of the dyads was monitored by living cell fluorescence imaging. Interestingly, extremely fast internalization was observed whose rate was temperature-dependent.
\end{abstract}

\section{INTRODUCTION}

Transition metal complexes have been considered as potential chemotherapeutic agents since the discovery of cisplatin (cisdiamminedichloridoplatinum(II)) by Rosenberg et al. in $1965 .{ }^{[1]}$ Despite numerous drawbacks such as high general toxicity, unselectivity, dose limited administration, acquired resistance to the drug, severe side effects, platinum-based drugs are still considered as the best candidates to treat cancer. ${ }^{[2]}$ To address these limitations, alternative metals have been investigated with variable success. ${ }^{[3-6]}$ Interestingly, some of them differ from cisplatin in their mode of action and target other biological sites than DNA. ${ }^{[7-11]}$ Understanding the behavior of these metallodrug candidates in living organisms would lead to the design of improved anticancer drugs but is still rather challenging. ${ }^{[12]}$

Very recently, organometallic half-sandwich $\operatorname{Ir}(\mathrm{III})$ complexes have attracted interest since they were found to exhibit anticancer activity on various cancer cell cultures including cisplatin-resistant cell line.$^{[6,13,14,15]}$ In particular, Sadler and coworkers introduced various complexes of the general formula $\left[\left(\mathrm{Cp}^{\mathrm{r}}\right) \operatorname{Ir}\left(\mathrm{X}^{\wedge} \mathrm{Y}\right) \mathrm{Z}\right]^{0 /+}$ where $\mathrm{Cp}^{\mathrm{r}}$ is pentamethylcyclopentadienyl $\mathrm{Cp}^{*}$ or its phenyl or biphenyl derivative, $\mathrm{X}^{\wedge} \mathrm{Y}$ is a chelating $\mathrm{N}^{\wedge} \mathrm{N}$ or $\mathrm{C}^{\wedge} \mathrm{N}$ bidentate ligand and $\mathrm{Z}$ an anionic chlorido or a neutral substituted pyridyl ligand. ${ }^{[6]}$ Interestingly, they reported that fine-tuning of the electronic and steric properties of the ligands modulates the chemical and biological activities of these transition metal complexes. For instance, introduction of phenyl or biphenyl substituents on Cp* improved the cytotoxicity of half-sandwich $\operatorname{Ir}(\mathrm{III})$ complexes. ${ }^{[13,16]}$ It was also established that the chelating ligand plays a key role in the activity of these complexes. Indeed, cytotoxicity of $\mathrm{Cp} * \operatorname{Ir}(\mathrm{III})$ complexes was switched on by introducing a $\mathrm{C}^{\wedge} \mathrm{N}$ chelating ligand in place of the $\mathrm{N}^{\wedge} \mathrm{N}$ ligand. While both complexes hydrolyze rapidly and bind with more or less affinity to model nucleobases, they essentially differ by their overall charge and thereby their lipophilicity (half-sandwich complexes with anionic $\mathrm{C}^{\wedge} \mathrm{N}$ ligands are neutral while those with a neutral $\mathrm{N}^{\wedge} \mathrm{N}$ ligand are cationic). This increased hydrophobic character gives in turn a much higher intracellular concentration of Ir which contributes to the cytotoxicity of $\left[\mathrm{Cp}^{*} \operatorname{Ir}\left(\mathrm{C}^{\wedge} \mathrm{N}\right) \mathrm{Cl}\right]$ complexes. ${ }^{[14,17]}$ Moreover, the antiproliferative activity of these complexes can be modulated by varying the nature and the position of the substituents on the $\mathrm{C}^{\wedge} \mathrm{N}$ chelating ligand. ${ }^{[18]}$ Finally, replacement of the chlorido ligand by a pyridyl ligand afforded monocationic complexes with enhanced cytotoxicity. This was attributed to the higher stability of these complexes towards aquation and side-reactions with intracellular deactivating components (i.e. glutathione), but also to their ability to increase the level of reactive oxygen species (ROS) in cancer cells. ${ }^{[19,20]}$ Other cyclometalated $\mathrm{Ir}(\mathrm{III})$ complexes were designed to target specific organelles showed theranostic properties by combining luminescent features and high photocytotoxicity on cancer cells. ${ }^{[21,22]}$ Another class of octahedral Ir(III) complexes behaved as potent and selective inhibitors of a protein kinase involved in angiogenesis. ${ }^{[23]}$ Nonetheless, the precise role of the different ligands and their influence in the mechanism of action of these metallodrug candidates on cell cultures is still not completely understood. Moreover, the method generally used to investigate cell uptake, subcellular distribution and specific accumulation of metallodrugs relies on cellular fractioning and subsequent metal assay by ICP-MS (Inductively Coupled Plasma Mass spectrometry). Although well-established and sensitive, this method does not allow dynamic process investigations.

In order to get further insight into the mechanism of action and the pharmacokinetics of these metallodrug candidates, faster, easily accessible and cost effective technologies need to be found. We thus propose an alternative strategy that relies on the design 
of metallodrug derivatives with fluorescence imaging capabilities. The following advantages are expected: information on uptake, localization and specific accumulation within living cells could be more easily acquired with the use of fluorescence microscopy instrumentation. Interestingly, cell cycle analysis, cell death detection and determination of the production of intracellular ROS are all assayed with fluorescent markers. These experiments could be carried out simultaneously with the fluorescent compound and co-localization by fluorescence microscopy would provide precious information on the behavior of the metallodrug candidate in a dynamic fashion.

In this perspective, we undertook to conjugate BODIPY (boron-dipyrromethene) fluorophores to a half-sandwich iridium (III) complex exhibiting anticancer properties in order to form theranostic metallodrug candidates. In this aim, the half-sandwich pentamethylcyclopentadienyl (Cp*) iridium (III) complex including 2-phenyl-pyridine (ppy) chelating ligand was selected as scaffold. Indeed, the chlorido precursor complex is easily accessible and displays a relatively good cytotoxicity (for example, $\mathrm{IC}_{50}$ value of $10.8 \mu \mathrm{M}$ against the A2780 human ovarian cancer), which should allow to acquire fluorescence images with nontoxic doses of fluorescent dye. BODIPYs are among the most attractive fluorophores currently available. They generally display high photostability, high quantum yield, neutral charge and sharp absorption and emission bands. ${ }^{[24,25]}$ Moreover, the optical properties of BODIPY are easily tunable via chemical modifications. ${ }^{[26,27]}$ Since BODIPY derivatives are also non toxic, ${ }^{[28]}$ they are especially useful for cell imaging studies and as biological probes. ${ }^{[29]}$ Only few examples of tethering of BODIPY to metal-based compounds with biological activity have been reported in the literature to date. ${ }^{[30-37]}$

The optical imaging reporter was introduced by replacing the labile coordinating chlorido ligand by a meso-pyridyl-BODIPY (py-BODIPY). The resulting iridium (III) complexes $\left[\left(\eta^{5}-\mathrm{Cp} *\right) \operatorname{Ir}(\mathrm{ppy})\left(3-\right.\right.$ or 4-pyridyl-BODIPY) $\mathrm{PF}_{6}($ Scheme 1$\left.)\right)$ were investigated for their photophysical properties, reactivity under model conditions (water, buffer, GSH, NADH), cytotoxicity and fluorescence cell imaging capabilities.

\section{RESULTS AND DISCUSSION}

Synthesis and Characterization of $\left[\left(\eta^{5}-\mathbf{C p}^{*}\right) \operatorname{Ir}(2\right.$-phenyl-pyridine)(3- or 4-pyridyl-BODIPY)]PF 6 Complexes. The starting materials $\left[\left(\eta^{5}-\mathrm{Cp} *\right) \operatorname{Ir}(\mathrm{ppy}) \mathrm{Cl}\right]^{[14]}$ as well as 3- and 4-pyridyl-BODIPY were synthesized according to previously reported methods. ${ }^{[38,39]}$ Compounds were fully characterized and their spectroscopic features are in agreement with the literature data.

Two novel BODIPY-Ir dyads were synthesized from the chlorido complex $\left[\left(\eta^{5}-\mathrm{Cp} *\right) \operatorname{Ir}(\mathrm{ppy}) \mathrm{Cl}\right]$ and isolated as $\mathrm{PF}_{6}$ salts. Complexes 1 and 2 were obtained by abstraction of the chlorido ligand with $\mathrm{AgNO}_{3}$ followed by addition of meso-3-pyridyl-BODIPY or meso-4-pyridyl-BODIPY. Finally, precipitation of the complexes was performed by addition of $\mathrm{NH}_{4} \mathrm{PF}_{6}(\mathrm{Scheme})$. The resulting complexes were fully characterized by ${ }^{1} \mathrm{H}$ and ${ }^{13} \mathrm{C}$ NMR spectroscopy (Figures S1 and S2 of the supporting information), ESIHRMS and X-ray crystallography (vide infra). Interestingly, the NMR analysis of the two complexes pointed out interesting differences between them. The BODIPY itself is known to have a deshielding effect on the protons of the pyridine ring owing to its electron withdrawing character. For compound 2, the BODIPY moiety is linked at position 4 affording complete resonance between the coordination site and the fluorescent part of the molecule. Consequently, metal complexation tended to balance the BODIPY deshielding effect and resulted in an overall downfield shift of the pyridine protons (Figure S3). On the other hand, the upfield shift of the methyl group protons at position 1 and 7 of the BODIPY was due to the anisotropic effect of the phenyl-pyridine ligand ($0.38 \mathrm{ppm}$ ). As for compound 1, the BODIPY entity was introduced at position 3 of the pyridine ring, so that its protons were no longer equivalent and resulted in a more complex spectrum. Moreover, the final iridium complex displayed a significant steric hindrance, as evidenced by the X-ray structure (Figure 1). Therefore, free rotation along the Ir-N bond was considerably disfavored and caused the formation of two different conformers. Thanks to 2D NMR experiments, we were able to distinguish the two conformers and to calculate a ratio of 4:1. Once again, a strong anisotropic effect was observed for one methyl of the BODIPY scaffold due to its proximity with the $\mathrm{C}^{\wedge} \mathrm{N}$ ligand rings $(-0.78 \mathrm{ppm})$.

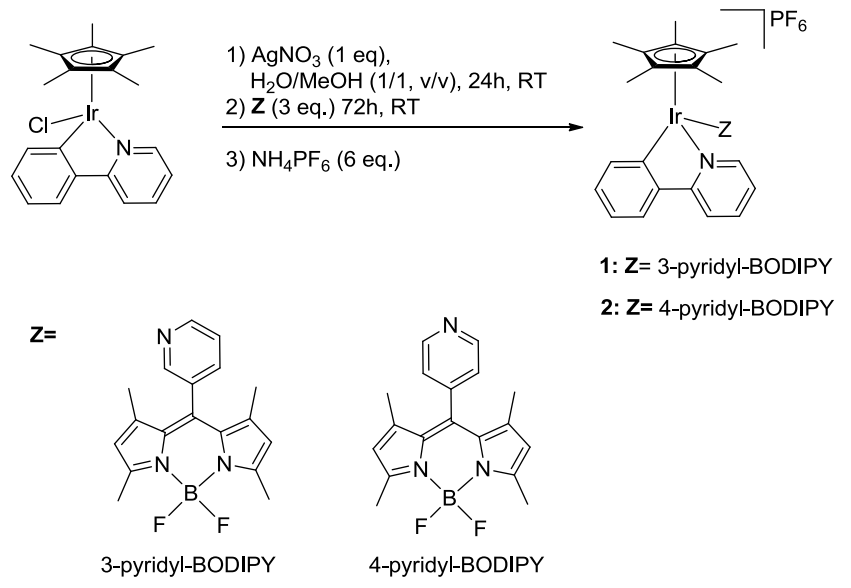

Scheme 1. Synthesis of Ir compounds studied in this work.

Owing to the possibly labile bond between the py-BODIPY entity and the Ir complex, it was anticipated that dissociation by exchange with other ligands (including solvent) may occur. The stability of the two complexes was studied by ${ }^{1} \mathrm{H}$ NMR in MeOD- $\mathrm{d}_{3}$ and DMSO- $\mathrm{d}_{6}$. As a good coordinating solvent, DMSO- $\mathrm{d}_{6}$ induced strong dissociation of the BODIPY (60\% dissociation was observed after $19 \mathrm{~h}$, full dissociation after $48 \mathrm{~h}$ for complexes 1 and $\mathbf{2}$ (see Figures S4 and S5). 
Table 1. Absorption and emission properties of BODIPY and Ir-BODIPY dyads in MeOH.

\begin{tabular}{|c|c|c|c|c|c|c|}
\hline Compound & $\lambda_{\max }(\mathrm{nm})^{\mathrm{a}}$ & $\varepsilon\left(\mathrm{M}^{-1} \cdot \mathrm{cm}^{-1}\right)^{\mathrm{b}}$ & $\lambda_{\text {em }}(\mathrm{nm})^{\mathrm{c}}$ & $\Phi^{\mathrm{d}}$ & $\tau(\mathrm{ns})^{\mathrm{e}}$ & Ref. \\
\hline 3-pyridyl-BODIPY ${ }^{f}$ & 502 & 85200 & 514 & 0.54 & 2.66 & {$[39]$} \\
\hline 4-pyridyl-BODIPY ${ }^{f}$ & 501 & 84700 & 514 & 0.46 & 1.44 & [39] \\
\hline 1 & 505 & 74900 & 514 & 0.29 & $2.76(81.5 \%)$ & This work \\
\hline 2 & 504 & 80400 & 516 & 0.14 & $1.17(81.5 \%)$ & This work \\
\hline
\end{tabular}

${ }^{a} \lambda_{\max }(\mathrm{nm})$ : absorption wavelength (at the maximum intensity); ${ }^{\mathrm{b}} \varepsilon\left(\mathrm{M}^{-1} . \mathrm{cm}^{-1}\right)$ : molar extinction coefficient; ${ }^{\mathrm{c}} \lambda_{\mathrm{em}}(\mathrm{nm})$ : emission wavelength (at the maximum intensity); ${ }^{\mathrm{d}} \Phi$ : fluorescence quantum yields; ${ }^{\mathrm{e}} \tau$ (ns): fluorescence lifetime.

However, in the presence of a weakly coordinating solvent such as $\mathrm{MeOH}$, no solvolysis was observed at ambient temperature over a period of 7 days. Since both complexes demonstrate a remarkable stability in $\mathrm{MeOH}$, this solvent was selected for further investigations.

Molecular Structures. Crystals of complexes 1 and $\mathbf{2}$ were obtained by slow evaporation from methanol at $273 \mathrm{~K}$ and were suitable for structure determination by X-ray diffraction. The molecular structure of complexes $\left[\left(\eta^{5}-\mathrm{Cp} *\right) \operatorname{Ir}(\mathrm{ppy})(3-\mathrm{pyridyl}-\right.$

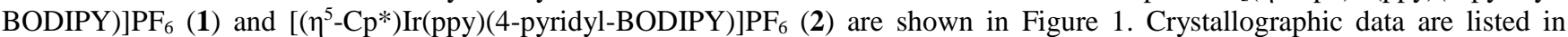
Tables $\mathrm{S} 1$ and $\mathrm{S} 2$.

Complexes 1 and $\mathbf{2}$ exhibit the expected pseudo-octahedral half-sandwich structure, with the Cp* ligand occupying three coordination sites, the ppy chelating ligand occupying two sites, and the monodentate meso-pyridyl BODIPY ligand occupying the sixth coordination position.
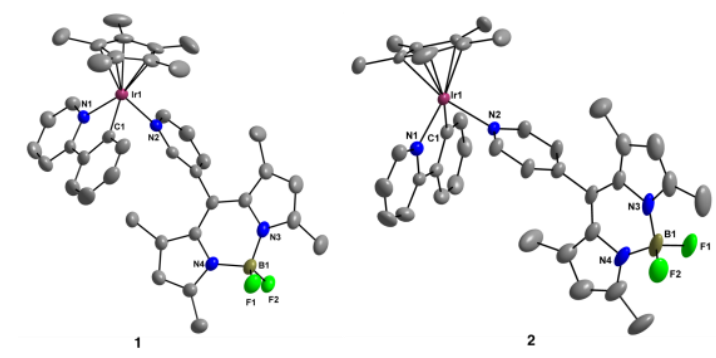

Figure 1. Crystal structures of compounds 1 and 2. Hydrogen atoms and PF 6 counterions have been omitted for clarity. Ellipsoids are shown at $50 \%$ probability.

Regarding the meso-pyridyl BODIPY entities, the dihedral angle between the pyridine substituent and the BODIPY moiety is $85^{\circ}$ and $93^{\circ}$ for $\mathbf{1}$ and $\mathbf{2}$, respectively, i.e. perpendicular configuration between the pyridine ring and the BODIPY. Thus, coordination did not change the configuration of the BODIPY entity. ${ }^{[39]}$ On the other hand, the structural parameters of complexes $\mathbf{1}$ and $\mathbf{2}$ were very similar to other cyclometalated Ir complexes comprising a pyridyl monodentate ligand. ${ }^{[19,20]}$

Photophysical properties of complexes 1 and 2. We next examined the photophysical properties of complexes $\mathbf{1}$ and $\mathbf{2}$ in $\mathrm{MeOH}$. As expected, both compounds displayed an intense and sharp absorption peak at $505\left(\varepsilon=74,900 \mathrm{M}^{-1} \cdot \mathrm{cm}^{-1}\right)$ and $504 \mathrm{~nm}$ $\left(\varepsilon=80,400 \mathrm{M}^{-1} \cdot \mathrm{cm}^{-1}\right)$, respectively (Table 1$)$. Complexation of the $\left(\mathrm{Cp}^{*}\right) \operatorname{Ir}(\mathrm{ppy})$ entity to meso-pyridyl-BODIPY induced a slight bathochromic shift $(3 \mathrm{~nm})$ as well as a slight broadening of the absorption band (Figure S6). Such a shift has been previously noticed for meso-pyridyl-BODIPY complexes of other metal ions. ${ }^{[30,39]}$

Complexes 1 and 2 also exhibited a typical fluorescence emission band at $514 \mathrm{~nm}$ and $516 \mathrm{~nm}$, respectively (Figure S7), i.e. identical to the free meso-pyridyl-BODIPY ligands. Interestingly, both complexes share a similar emission profile with rather high quantum yield $\left(\Phi_{\mathrm{f}}=29 \%\right.$ for 1 and $\Phi_{\mathrm{f}}=14 \%$ for 2$)$. Nonetheless, partial quenching was noticed upon complexation of the organometallic entity (46\% and $70 \%$ for 3- and for 4-pyridyl BODIPY, respectively). This is reminiscent of an analogous half-sandwich $\mathrm{Ru}$ (II) complex including the 4-pyridyl BODIPY entity for which quenching also reached $71 \%$. ${ }^{[30]}$ This effect was explained by intramolecular photoinduced electron transfer (PET) from meso-pyridyl-BODIPY to the $\left[(p-c y m) \mathrm{Ru}\left(\mathrm{N}^{\wedge} \mathrm{N}\right)\right]$ moiety. ${ }^{[30,31]} \mathrm{It}$ is important to note that even if complexation induces a significant quench, both complexes still display high quantum yield (Table 1). In the literature, another cyclometalated half-sandwich Ir complex where the BODIPY moiety was included in the $\mathrm{C}^{\wedge} \mathrm{N}$ ligand displayed a drastically decreased quantum yield compared to the parent $\mathrm{C}^{\wedge} \mathrm{N}$ ligand $(\Phi=0.1 \%$ vs. $45.2 \%)$ owing to more efficient PET quenching in this case. ${ }^{[40]}$

Emission features were conserved in aqueous medium but the quantum yield of complexes $\mathbf{1}$ and $\mathbf{2}$ dropped down to 8.4 and $5 \%$, respectively. Since complex $\mathbf{1}$ displays better photophysical properties than $\mathbf{2}$, we decided to focus on compound $\mathbf{1}$ for further investigation.

Photoinduced ligand dissociation of complex 1. Dicationic isoelectronic Ru(II) complexes containing a monodentate pyridine ligand are known to be light-sensitive and pyridine dissociates upon irradiation with white light. ${ }^{[30,31,41]}$ Therefore, we investigated whether 3-pyridyl-BODIPY dissociated from complex 1 upon continuous irradiation at $470 \mathrm{~nm}$ by fluorescence spectroscopy. The emission intensity of PBS solutions of $\mathbf{1}$ and 3-pyridyl BODIPY at $37^{\circ} \mathrm{C}$ at $512 \mathrm{~nm}$ was recorded for 15 min (Figure S8). Negligible 
photodissociation of $\mathbf{1}$ and photobleaching of 3-pyridyl-BODIPY were observed. Taken together, all these observations confirm the remarkable chemical and photochemical stability of our dyad under physiological conditions. We anticipate that dyad $\mathbf{1}$ should be suitable for cellular imaging studies by fluorescence microscopy.

Hydrolysis Studies. We then investigated the long-term behavior of compound $\mathbf{1}$ in PBS since it may be prone to aquation leading to the dissociation of the free BODIPY ligand. Moreover, aquation is often presented as a crucial activation step for anticancer metal complexes. ${ }^{[42]}$ The fate of complex 1 in PBS was monitored by absorption spectroscopy. The absorption spectrum of 1 was recorded over a period of $16 \mathrm{~h}$ (Figure S9). The maximum progressively underwent a slight hypsochromic shift as well as a slight increase of the intensity assigned to the partial dissociation of the meso-pyridyl-BODIPY entity from the complex. Based on the variation of absorbance, the magnitude of dissociation was calculated to be ca. $28 \%$ after $16 \mathrm{~h}$. This finding is in good agreement with the increased hydrolytic stability noticed for pyridyl complexes with respect to the corresponding chlorido complexes. ${ }^{[19]}$

Reaction of 1 with NADH. It has been previously shown that cyclometalated half-sandwich $\operatorname{Ir}(\mathrm{III})$ complexes with either $\mathrm{Z}=\mathrm{Cl}$ or pyridine are able to oxidize $\mathrm{NADH}$ by hydride transfer to the metal center which is further transferred to $\mathrm{O}_{2}$ to yield $\mathrm{H}_{2} \mathrm{O}_{2} \cdot{ }^{[18,19]}$ We investigated whether dyad 1 had the same property. When complex $\mathbf{1}$ or $\left[\left(\eta^{5}-\mathrm{Cp} *\right) \operatorname{Ir}(\mathrm{ppy}) \mathrm{Cl}\right]$ was added to a solution of NADH in PBS, the UV spectrum of NADH gradually changed as the absorbance at $340 \mathrm{~nm}$ decreased while the absorbance at $260 \mathrm{~nm}$ simultaneously increased (Figure S10). This is typical of the oxidation of NADH to NAD ${ }^{+}$. The reaction followed a first-order kinetics with $\mathrm{k}_{\mathrm{obs}}$ of $0.0018 \mathrm{~min}^{-1}$ and $0.003 \mathrm{~min}^{-1}$ for 1 and $\left[\left(\eta^{5}-\mathrm{Cp} \mathrm{p}^{*}\right) \operatorname{Ir}(\mathrm{ppy}) \mathrm{Cl}\right]$, respectively and TON of 3.6 and 5.5 at $14 \mathrm{~h}(\mathrm{Fig}-$ ure S11). On the whole, appending of a py-BODIPY entity to the complex did not alter in the least the chemical reactivity of the complex.

Partition Coefficients $(\log \mathbf{P})$. The cytotoxic potency of a drug is generally related to its cellular accumulation, which is in turn related to its lipophilicity. In general, hydrophobicity is considered to play a crucial role in structure-activity relationships and in determining the biological properties of the drug. ${ }^{[14,43]}$ The octanol-water partition coefficient $(\log P$ ) of complex $\mathbf{1}$ was determined by an HPLC method introduced by Minick et al. ${ }^{[44]}$ and Pomper et al. ${ }^{[45]}$ Despite its cationic character, complex 1 displays a positive $\log P$ value of 4.19. This is attributed to the presence of the py-BODIPY ligand that is itself highly hydrophobic (log $P$ of 3 pyridyl-BODIPY= 3.66).

Cytotoxicity studies. Complex 1 was evaluated for its cytotoxic activity on various cancer cell lines, namely human ovarian A2780/A2780-cisplatin resistant (acquired resistance to cisplatin) and human breast MDA-MB-231. For comparison, cell viability assays were also performed on MRC-5 human normal fibroblasts (Table 2). Since the complex is insoluble in aqueous medium and prone to dissociation in DMSO, stock solutions were prepared in $\mathrm{MeOH}$. They were serially diluted in complete culture medium so that the final concentration of $\mathrm{MeOH}$ did not exceed $0.1 \%$.

Table 2. Cytotoxic activity of 1 expressed as $\mathrm{IC}_{50}$ value and comparison with $[\mathrm{Cp} * \operatorname{Ir}(\mathrm{ppy}) \mathrm{CI}](\mu \mathrm{M})$.

$\begin{array}{lll}\text { Cell line } & \text { Complex 1 } & {\left[\left(\eta^{5}-\mathrm{Cp} \mathrm{p}^{*}\right) \operatorname{Ir}(\mathrm{ppy}) \mathrm{Cl}\right]} \\ \text { A2780 } & 0.56 \pm 0.04 & 14.0 \pm 2.84 \\ \text { A2780cis } & 1.08 \pm 0.05 & 20.8 \pm 4.40 \\ \text { MDA-MB-231 } & 0.52 \pm 0.03 & \text { n.d } \\ \text { MRC-5 } & 2.35 \pm 0.09 & 24.9 \pm 2.01 \\ \log P & 4.19 & 1.57^{\mathrm{b}} \\ { }^{\mathrm{a}} \text { Drug-treatment period was } 72 \mathrm{h.}^{\mathrm{b}} \operatorname{Ref}^{[14]} .\end{array}$




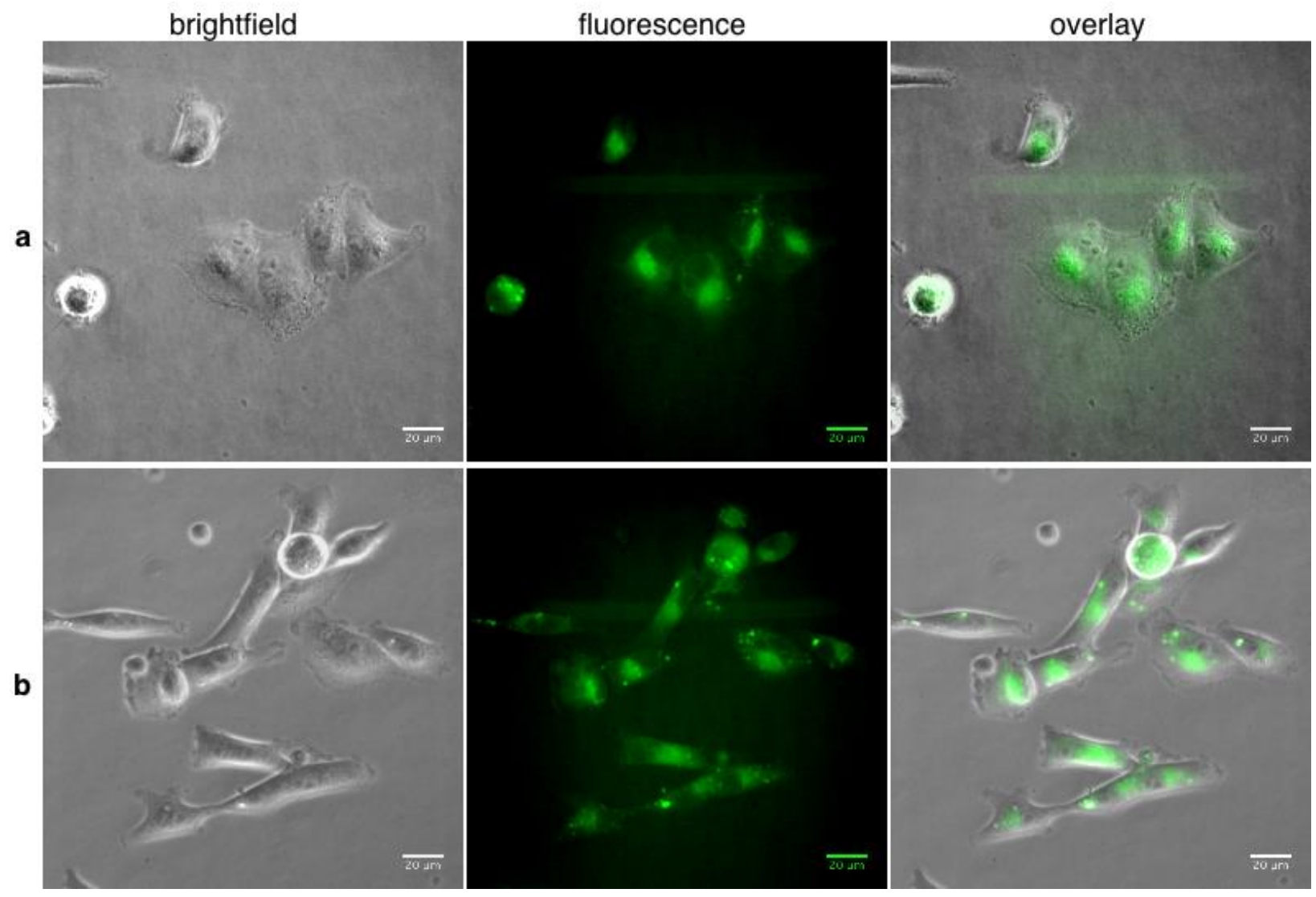

Figure 2. Living MDA-MB-231 cells treated with $500 \mathrm{nM}$ of (a) 1 or (b) 3-pyridyl-BODIPY in culture medium for 30 min at $37^{\circ} \mathrm{C}$. For fluorescence observation, filters were $450-490 \mathrm{~nm}$ for excitation and $500-550 \mathrm{~nm}$ for emission.

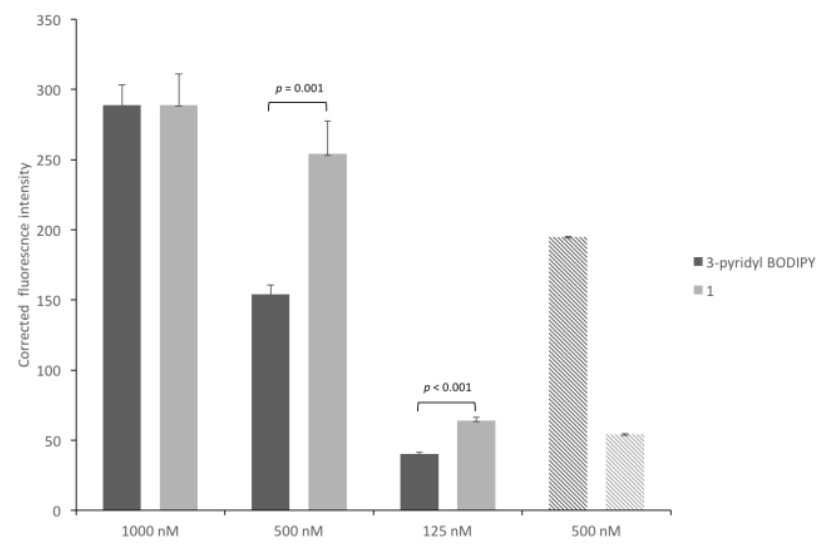

Figure 3. Average of the mean fluorescence intensity for collections of cells incubated with $125 \mathrm{nM}(37 \mathrm{cells}), 500 \mathrm{nM}(34$ cells) or $1000 \mathrm{nM}$ (42 cells) of 3-pyridyl-BODIPY or with $125 \mathrm{nM}$ (67 cells), $500 \mathrm{nM}$ (56 cells) or $1000 \mathrm{nM}$ (53 cells) of compound 1 for 30 min at $37^{\circ} \mathrm{C}$. Hatched bars represent the fluorescence intensity of $500 \mathrm{nM}$ solutions of 3-pyridyl-BODIPY and 1 in PBS measured on a spectrofluorimeter.

Compound 1 exhibits high potency with submicromolar $\mathrm{IC}_{50}$ on $\mathrm{A} 2780$ cell line $(560 \mathrm{nM})$. Interestingly, complex 1 is also able to overcome the cisplatin resistance in human ovarian A2780 cancer cell line and displays four times less toxicity towards normal cells (MRC-5 human lung fibroblast cells) than towards A2780 cell line. Let us note that both 2- and 4-pyridyl-BODIPY are known to be non cytotoxic. ${ }^{[28,32]}$ We also checked that 3-pyridyl-BODIPY had no effect on MDA-MB231 cell growth at $10 \mu \mathrm{M}$. The high cancer cell cytotoxicity of $\mathbf{1}$ could arise from its high lipophilicity and its stability towards hydrolysis, as it was already the case for compounds of the same family developed by Sadler. ${ }^{[20]}$

Cell imaging studies. MDA-MB-231 cells were exposed to 3-pyridyl-BODIPY or to complex 1 at $500 \mathrm{nM}^{\circ} 37^{\circ} \mathrm{C}$ in $5 \% \mathrm{CO}_{2}$ atmosphere and subsequently imaged with an epifluorescence wide field microscope. Figure 2 shows representative living cell images acquired after $30 \mathrm{~min}$ incubation. Fluorescence emission was detected indistinctly in most cells exposed to 1 and 3-pyridylBODIPY as large diffuse zones and small bright spots in the cytoplasm. This first experiment gave strong evidence that both compounds were membrane-permeant and accumulated in cells. Interestingly, the images resembled those obtained with 2-pyridyl- 
BODIPY for which distribution in the Golgi apparatus and in lipid droplets and lysosomes was deduced from morphological analysis of cells. ${ }^{[28]}$ The remarkable lipophilicity of $\mathbf{1}$ may induce a different and probably higher cell accumulation when compared to the complexes developed by Sadler, ${ }^{[13,18]}$ which are reported to preferentially accumulate in the membrane fraction and in cytosol. It might be the sign of a different mechanism of action for complex 1. This experiment was repeated with two other concentrations of both fluorescent compounds (1000 and $125 \mathrm{nM}$ ) and average fluorescence intensity was measured in a number of cells between 37 and 67 (Figure 3). A relationship between the initial concentration of both fluorescent dyes added to the culture medium and the average intensity in cells could be established. At the two lowest concentrations (500 and $125 \mathrm{nM}$ ), the average fluorescence intensity was significantly higher for cells exposed to $\mathbf{1}$ in comparison to $\mathrm{N}_{3}$-py-BODIPY as deduced from an unpaired Student's t-test. Since the quantum yield of the former is ca. 3 times lower than that of the latter in PBS (see Figure 3, right part), we may reasonably assume that the amount of $\mathbf{1}$ accumulated in cells is higher than the amount of $\mathrm{N}_{3}$-py-BODIPY.

Thanks to the remarkable photostability of BODIPY dyes, it was possible to monitor the uptake of both compounds in living cells in real time. Very soon (less than $10 \mathrm{~s}$ ) after injection of $\mathbf{1}$ in the medium, fluorescence was detected inside cells maintained at $37^{\circ} \mathrm{C}$. The emission intensity increased continuously and reached a maximum after ca. $90 \mathrm{~s}$. Thus cell internalization was very rapid (see movie in SI). Quantitative analysis was applied to the background corrected intensity data to calculate the rate constant (assuming first order kinetics). Real time monitoring of internalization of compound $\mathbf{1}$ was also performed at low temperature (Figure S12) and the corresponding rate constant calculated accordingly (Figure 4).

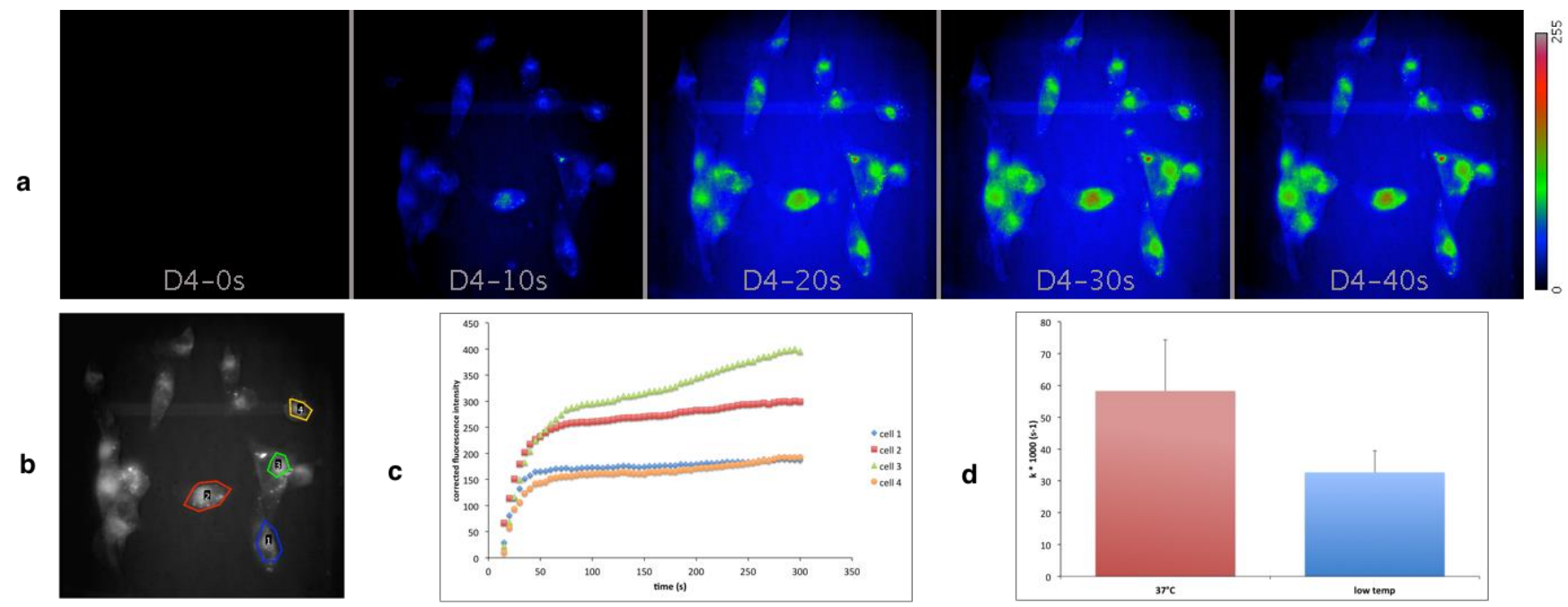

Figure 4. Real time monitoring of uptake of compound 1 by MDA-MB-231 cells. (a) Fluorescence images of living cells exposed to $500 \mathrm{nM}$ of 1 at $37^{\circ} \mathrm{C}$ at selected time points. (c) Time course of background corrected fluorescence intensity in four cells (shown in (b)). (d) Average rate constants of internalization of 1 at $37^{\circ} \mathrm{C}$ and low temperature (measured in four and three cells, respectively).

It appeared that the rate of internalization decreased significantly when the temperature was decreased which indicates that energy-dependent transport processes might be involved in cell uptake of compound $\mathbf{1}$.

\section{CONCLUSION}

Two iridium-BODIPY dyads were synthesized by a procedure involving the replacement of the anionic chlorido ligand of $\left[\left(\eta^{5}-\right.\right.$ $\left.\mathrm{Cp}^{*}\right) \operatorname{Ir}(\mathrm{PhPy}) \mathrm{Cl}$ ] by neutral meso-pyridyl BODIPY ligands to afford the monocationic, highly lipophilic complexes $\mathbf{1}$ and $\mathbf{2}$. The molecular structure of both complexes was confirmed by X-ray crystallography. Judicious positioning of the BODIPY entity allowed the dyads to maintain a high quantum yield as well as potent antiproliferative activity on a range of cancer cell lines. The presence of the BODIPY entity as fluorescence imaging reporter provided very useful information on the dynamics of cell uptake, accumulation and distribution of the metallodrug in living cells. Owing to the outstanding chemical and photophysical properties of the BODIPY reporter, we expect this approach to provide clues on the activation and the mechanism of action of non-platinum metallodrug candidates. For this purpose, fluorescence co-localization experiments with living cells will be undertaken with complex 1. Correlations between hydrophobicity, cellular accumulation and activity will be drawn, along with comparison of cellular distribution of 1. Moreover, py-BODIPY ligands displaying distinct photophysical properties in their metal-bound and free forms are under investigation. These new dyads should provide useful information regarding metallodrug activation through their imaging in living cells. In fine, this piece of work may provide the first step towards in vivo imaging of metallodrug candidates.

\section{EXPERIMENTAL SECTION}

General Considerations. ${ }^{1} \mathrm{H}$ and ${ }^{13} \mathrm{C}$ spectra were recorded on Bruker Avance 400 and 600 spectrometers and calibrated to the residual solvent peak: DMSO- $\mathrm{d}_{6}\left({ }^{1} \mathrm{H}: 2.50 \mathrm{ppm}\right)$ and $\mathrm{CD}_{2} \mathrm{Cl}_{2}\left({ }^{1} \mathrm{H}\right.$ : $\left.5.32 \mathrm{ppm} ;{ }^{13} \mathrm{C}: 54.00 \mathrm{ppm}\right)$. Peaks are reported with their corresponding multiplicity (s: singlet; d: doublet, t: triplet; m: multiplet), peak shifts are reported in ppm, integration and respective $J$ coupling constants are given in Hertz.

Mass Spectrometry. Exact mass measurements (HRMS) were obtained on TQ R30-10 HRMS spectrometer by ESI+ ionization and are reported in $\mathrm{m} / \mathrm{z}$ for the major signal. Samples were prepared in DCM. The mass spectra were recorded with a scan range of $\mathrm{m} / \mathrm{z} 400-1000$ for positive ions. 
$U V$-Visible spectra were recorded on a Cary 50 spectrophotometer (Varian) equipped with a temperature controlled element or a Lambda 45 spectrophotometer (Perkin Elmer).

Steady-state fluorescence spectra were recorded on a FP-6200 spectrofluorimeter (Jasco) at $20 \pm 0.1{ }^{\circ} \mathrm{C}$ with excitation set at $470 \mathrm{~nm}$. Excitation and emission bandwidths were set to $5 \mathrm{~nm}$ and scan rate to $125 \mathrm{~nm} / \mathrm{min}$.

Fluorescence lifetimes were measured on a Fluoromax-4 spectrofluorimeter equipped by TCSPC accessory (Horiba) using the time domain technique. Absolute fluorescence quantum yields were measured on the same spectrofluorimeter equipped with the integrating sphere Quanta.

Chemicals. 2-Phenylpyridine, $\mathrm{AgNO}_{3}, \mathrm{NH}_{4} \mathrm{PF}_{6}, 4$-pyridinecarboxaldehyde, 3-pyridinecarboxaldehyde, boron trifluoride diethyl etherate $\left(\mathrm{BF}_{3} \cdot \mathrm{Et}_{2} \mathrm{O}, 98 \%\right)$, and DIEA were purchased from Sigma-Aldrich. 2,4-dimethylpyrrole and $p$-chloranil were purchased from TCI Europe N.V.. $\left[\left(\eta^{5}-\mathrm{Cp}^{*}\right) \operatorname{Ir}(\mathrm{ppy}) \mathrm{Cl}\right]^{[16]}, 3$-pyridyl-BODIPY and 4-pyridyl-BODIPY were prepared according to reported methods. ${ }^{[38,39]}$

Syntheses. Complexes 1 and 2 were prepared by the same method: A solution of the chlorido complex $\left[\left(\eta^{5}-\mathrm{Cp} *\right) \operatorname{Ir}(\mathrm{ppy}) \mathrm{Cl}\right](31 \mathrm{mg}, 0.06 \mathrm{mmol}$, 1 equiv.) and $\mathrm{AgNO}_{3}(10.2 \mathrm{mg}, 0.06 \mathrm{mmol}, 1$ equiv.) in $\mathrm{MeOH}$ and water (1:1, v/v, $12 \mathrm{~mL}$ ) was stirred for 16h in the dark. The precipitate (AgCl) was removed by filtration through Celite, and 3- or 4-pyridyl-BODIPY ( $58.5 \mathrm{mg}, 0.18 \mathrm{mmol}, 3$ equiv.) was added to the filtrate. The reaction mixture was stirred at ambient temperature. After $72 \mathrm{~h}$, excess pyridine derivatives were removed by filtration and $\mathrm{NH}_{4} \mathrm{PF}_{6}(54.8 \mathrm{mg}, 0.34 \mathrm{mmol}, 6$ equiv.) was added to the filtrate. The resulting red-vermillion precipitate was collected by filtration, washed with diethyl ether, and recrystallized from methanol/diethyl ether to yield vermillion powders. Crystals of both complexes were suitable for X-ray diffraction and were obtained by slow evaporation of methanol at $4{ }^{\circ} \mathrm{C}$

$\left[\left(\eta^{5}-C p^{*}\right) \operatorname{Ir}(2-\right.$ phenyl-pyridine $\left.)(3-p y r i d y l-B O D I P Y)\right] P F_{6}(\mathbf{1}) .(12.5 \mathrm{mg}, 0.013 \mathrm{mmol}, 22 \%) .{ }^{1} \mathrm{H} \mathrm{NMR}\left(600 \mathrm{MHz}, \mathrm{CD}_{2} \mathrm{Cl}_{2}\right): \delta 8.97(\mathrm{~d}, 1 \mathrm{H}, J=5.65$ $\left.\mathrm{Hz}, \mathrm{H}_{\mathrm{py}}\right), 8.70\left(\mathrm{~d}, 1 \mathrm{H}, J=5.65 \mathrm{~Hz}, \mathrm{H}_{\text {py-BODIPY}}\right), 8.24\left(\mathrm{bs}, 1 \mathrm{H}, \mathrm{H}_{\mathrm{py}-\text {-BODIPY}}\right), 7.90\left(\mathrm{~m}, 1 \mathrm{H}, \mathrm{H}_{\text {py-BODIPY}}\right), 7.85\left(\mathrm{~m}, 2 \mathrm{H}, \mathrm{H}_{\mathrm{ar}}\right), 7.67\left(\mathrm{~m}, 2 \mathrm{H}, \mathrm{H}_{\mathrm{ar}}+\mathrm{H}_{\mathrm{py}-\mathrm{BODIPY}}\right)$,

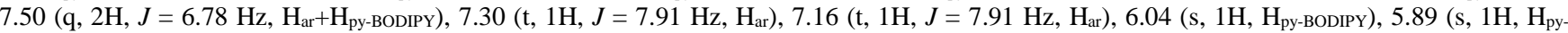

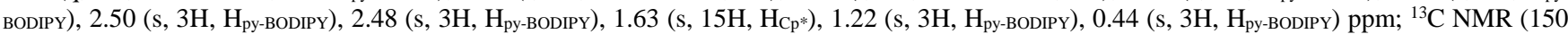

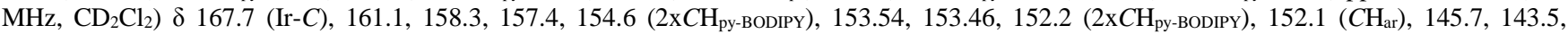
142.1, $140.0\left(\mathrm{CH}_{\mathrm{ar}}\right), 139.8\left(\mathrm{CH}_{\mathrm{ar}}\right), 135.8,135.6\left(\mathrm{CH}_{\mathrm{ar}}\right), 134.2,133.1\left(\mathrm{CH}_{\mathrm{ar}}\right), 128.5\left(\mathrm{CH}_{\mathrm{ar}}\right), 125.6\left(\mathrm{CH}_{\mathrm{ar}}\right), 125.0(\mathrm{CH}), 124.9\left(C \mathrm{H}_{\mathrm{ar}}\right), 122.65$

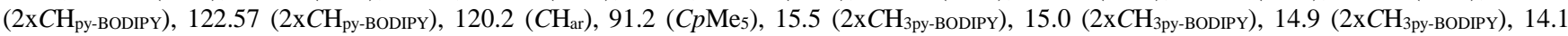
(2xCH3py-BODIPY), 9.1 (CpMes) ppm; HRMS (ESI): [M]+ found: 807.3054, calcd. for $\mathrm{C}_{39} \mathrm{H}_{41} \mathrm{BF}_{2} \mathrm{IrN}_{4}$ 807.3025. Crystal data for 1: orange prismatic crystals: $\mathrm{C}_{39} \mathrm{H}_{41} \mathrm{BF}_{8} \mathrm{IrN}_{4} \mathrm{P}$, monoclinic, $P 2_{1} / n, \mathrm{a}=11.2116(6), \mathrm{b}=20.458(2), \mathrm{c}=16.9203(9) \AA, \beta=94.424(2){ }^{\circ}, \mathrm{V}=3869.3(5) \AA^{3}, \mathrm{Z}=4, \mathrm{~T}=$ 200(2) K, CCDC 1538935.

$\left[\left(\eta^{5}-C p^{*}\right) \operatorname{Ir}(2-p h e n y l-p y r i d i n e)(4-p y r i d y l-B O D I P Y)\right] P F_{6}(2) .(15 \mathrm{mg}, 0.016 \mathrm{mmol}, 26 \%) .{ }^{1} \mathrm{H} \mathrm{NMR}\left(600 \mathrm{MHz}, \mathrm{CD}_{2} \mathrm{Cl}_{2}\right): \delta 8.95(\mathrm{~d}, 1 \mathrm{H}, J=5.27$ $\left.\mathrm{Hz}, \mathrm{H}_{\mathrm{py}}\right), 8.46\left(\mathrm{~d}, 2 \mathrm{H}, J=5.65 \mathrm{~Hz}, \mathrm{H}_{\mathrm{py}-\mathrm{BODIPY}}\right), 7.95\left(\mathrm{~d}, 1 \mathrm{H}, J=7.53 \mathrm{~Hz}, \mathrm{H}_{\mathrm{ar}}\right), 7.87\left(\mathrm{t}, 1 \mathrm{H}, J=7.15 \mathrm{~Hz}, \mathrm{H}_{\mathrm{ar}}\right), 7.83\left(\mathrm{~d}, 1 \mathrm{H}, J=7.53 \mathrm{~Hz}, \mathrm{H}_{\mathrm{ar}}\right), 7.67(\mathrm{~d}$,

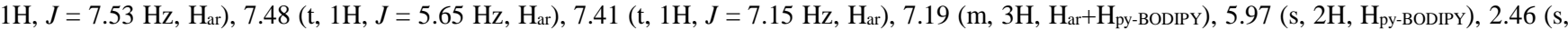
$\left.6 \mathrm{H}, \mathrm{H}_{\mathrm{py}-\mathrm{BODIPY}}\right), 1.67$ (s, 15H, $\mathrm{H}_{\mathrm{Cp}}$ ), 1.04 (s, 6H, $\left.\mathrm{H}_{\mathrm{py}-\mathrm{BODIPY}}\right) \mathrm{ppm} ;{ }^{13} \mathrm{C} \mathrm{NMR}\left(150 \mathrm{MHz}, \mathrm{CD}_{2} \mathrm{Cl}_{2}\right): \delta 167.5(\mathrm{Ir}-\mathrm{C}), 161.3,157.7,154.6\left(2 \mathrm{xCH} \mathrm{H}_{\mathrm{py}}\right.$ BODIPY $), 151.9\left(\mathrm{CH}_{\mathrm{ar}}\right), 146.8,145.5,142.6,139.9\left(\mathrm{CH}_{\mathrm{ar}}\right), 135.4,135.2\left(\mathrm{CH}_{\mathrm{ar}}\right), 133.0\left(C_{\mathrm{ar}}\right), 130.2,127.4\left(2 \times C \mathrm{H}_{\mathrm{py}-\mathrm{BODIPY}}\right), 125.5\left(C \mathrm{H}_{\mathrm{ar}}\right), 125.1$ $\left(\mathrm{CH}_{\mathrm{ar}}\right), 124.8\left(\mathrm{CH}_{\mathrm{ar}}\right), 122.7\left(2 \mathrm{x} C \mathrm{H}_{\mathrm{py}-\mathrm{BODIPY}}\right), 120.1\left(\mathrm{CH}_{\mathrm{ar}}\right), 91.1(\mathrm{CpMe}), 14.9\left(2 \mathrm{x} C \mathrm{H}_{3 \mathrm{py}-\mathrm{BODIPY}}\right), 14.6\left(2 \mathrm{x} C \mathrm{H}_{3 \mathrm{py}-\mathrm{BODIPY}}\right), 8.9(\mathrm{CpMe}) \mathrm{ppm} ; \mathrm{HRMS}$ (ESI): $[\mathrm{M}]^{+}$found: 807.2992 , calcd. for $\mathrm{C}_{39} \mathrm{H}_{41} \mathrm{BF}_{2} \mathrm{IrN}_{4}$ 807.3025. Crystal data for 2: red prismatic crystals: $\mathrm{C}_{39} \mathrm{H}_{42} \mathrm{BF}_{8} \mathrm{IrN}_{4} \mathrm{P}$, triclinic, $P-1, \mathrm{a}=$ $10.2318(4), b=10.6061(5), c=18.6360(8) \AA, \alpha=81.2380(10), \beta=79.6340(10), \gamma=84.023(2)^{\circ}, \mathrm{V}=1960.01(15) \AA^{3}, \mathrm{Z}=2, \mathrm{~T}=200(2) \mathrm{K}, \mathrm{CCDC}$ 1538936. For detailed information, see SI.

Hydrolysis. Aquation of $\mathbf{1}$ and $\mathbf{2}$ was monitored by recording uv-visible spectra of $10 \mu \mathrm{M}$ solution in PBS/MeOH $99 / 1$ each 10 or 30 min for 16 $\mathrm{h}$ at room temperature.

Reaction with NADH. A solution containing NADH $(146 \mu \mathrm{M})$ and 1 or $2(10 \mu \mathrm{M})$ in PBS/MeOH 99/1 was incubated at $37^{\circ} \mathrm{C}$. Uv-vis spectra were recorded each $30 \mathrm{~min}$ for $14 \mathrm{~h}$. Non linear regression analysis of data was performed with Kaleidagraph to determine the rate constant.

$\log$ P Determination. Partition coefficients $\log \mathrm{P}$ were determined by a reverse-phase HPLC polycratic method introduced by Minick et al. ${ }^{[44]}$ HPLC measurements were carried out on a Jasco chromatographic system including pumps P2080 and P2987 and a uv-vis detector (uv-2075 Plus) set at $510 \mathrm{~nm}$. The stationary phase was a Nucleosil C18 Htec $5 \mu \mathrm{m}, 4.6$ x $150 \mathrm{~mm}$ column (Macherey-Nagel). Mobile phase A was $20 \mathrm{mM}$ MOPS, $0.15 \%$ decylamine (v/v) pH 7.4 in water saturated with 1-octanol and mobile phase B was $0.25 \% 1$-octanol (v/v) in MeOH. In brief, solutions of 1 or 2 in $\mathrm{MeOH}(100 \mu \mathrm{M})$ spiked with uracile $(250 \mu \mathrm{M})$ as unretained internal reference were repetitively injected in the column equilibrated with mobile phase B between 60 and $75 \%$ at $1 \mathrm{ml} / \mathrm{min}$. The $\log \mathrm{k}^{\prime}{ }_{\mathrm{w}}$ was determined by $\operatorname{linear}$ extrapolation of $\log \mathrm{k}$ ' at $\% \mathrm{~B}=0 . \log \mathrm{P}$ were calculated from the equation established by Pomper et al. ${ }^{[45]}$

$\log \mathrm{P}=0.13418+0.98452 * \log \mathrm{k}^{\prime}{ }_{\mathrm{w}}$

Cytotoxicity assays. MRC-5 cell line derived from normal lung tissue was obtained from the American Type Culture Collection (ATCC, Rockville, MD) and ovarian and breast cancer cell lines (A2780, A2780-Cis and MDA-MB-231) were obtained from the European collection of cell culture (ECACC, England). Cell lines were cultured according to the supplier's instructions. A2780 and A2780-Cis cells were grown in Gibco medium RPMI 1640 supplemented with 10\% fetal calf serum (FCS) and 1\% glutamine. Human MRC-5 cells were grown in DMEM supplemented with $10 \%$ fetal calf serum (FCS) and $1 \%$ glutamine. Cells were counted using a Vi-cell XR (Beckman Coulter) and their viability assessed by $0.25 \%$ trypan blue dye exclusion. They were tested for the presence of mycoplasma before experiments with the Mycoplasma PCR Detection Kit (Applied Biological Materials Inc., Canada) in accordance with the manufacturer instructions and only mycoplasma-free cells were used for further investigations.

Cell lines were maintained at $37^{\circ} \mathrm{C}$ in a humidified atmosphere containing $5 \% \mathrm{CO}_{2}$. Cell growth inhibition was determined by an MTS assay according to the manufacturer's instructions (Promega, Madison, WI, USA). For IC 50 determination, the cells were seeded in 96-well plates $\left(3 \times 10^{3}\right.$ cells/well) containing $100 \mu \mathrm{L}$ of growth medium. After $24 \mathrm{~h}$ of culture, the cells were treated with the tested compounds at 10 different final concentrations. Each concentration was obtained from serial dilutions of $\mathbf{1}$ in culture medium starting from a $2 \mathrm{mM}$ stock solution in MeOH with a final proportion of $\mathrm{MeOH}$ equal to $0.1 \%$ (v/v). Control cells were treated with the vehicle. Experiments were performed in triplicate.

After $72 \mathrm{~h}$ of incubation, $20 \mu \mathrm{L}$ of CellTiter 96® AQueous One Solution Reagent was added for $2 \mathrm{~h}$ before recording absorbance at $490 \mathrm{~nm}$ with a spectrophotometric plate reader Softmax 384 plus (Molecular devices Sunnyvale, California). The dose-response curves were plotted with Graph Prism software and the $\mathrm{IC}_{50}$ values were calculated using the Graph Prism software from polynomial curves.

Cell imaging studies. MDA-MB-231 cells (50000 cells) in $1 \mathrm{ml}$ DMEM supplemented with $9 \%$ fetal calf serum, $0.9 \%$ Glutamax I and $0.9 \%$ kanamycin were seeded in 24-well sterile plates and grown for $24 \mathrm{~h}$ under an humidified atmosphere of $5 \% \mathrm{CO}_{2}$ in air at $37^{\circ} \mathrm{C}$. The following day, $1 \mathrm{ml}$ of the same medium containing the appropriate concentration of $\mathrm{N}_{3}$-py-BODIPY or 1 was added to the wells and imaged during up to 30 min. Image acquisition was performed with an inverted videomicroscope (Zeiss Axiovert 200M) equiped with an x40 NA 0.5 objective, a black and white CCD camera (Evolve512 Photometrics, Roper Scientific France) driven with Metamorph software (Molecular devices). For fluorescence observation, bandpass filters (Chroma, Roper Scientific France) were 450-490 nm for excitation and 500-550 nm for emission. Temperature de- 
pendent internalization was studied after 10 min cell plate incubation on ice before product addition. Fluorescence quantification was performed with Fiji software. ${ }^{[46]}$

\section{ASSOCIATED CONTENT}

\section{Supporting Information}

Spectroscopic and kinetic data (PDF)

Movie of cellular uptake of compound 1 monitored by videomicroscopy (AVI)

\section{AUTHOR INFORMATION}

\section{Corresponding Author}

* M.S.: email: Michele.salmain@ upmc.fr; phone: +33 1 44276732. S.T.: email: serge.thorimbert@ upmc.fr; phone: +33 144273084 Notes

All authors contributed significantly to the design of the experiments and their execution, to the analysis of the data and to the writing of the manuscript. The authors declare no competing financial interest.

\section{ACKNOWLEDGMENT}

This work was financially supported by the LabEx MiChem part of French state funds managed by the ANR within the Investissements d'avenir programme under reference ANR-11-IDEX-004-02. Image acquisition was performed at the imaging facility PICPS "Plateforme d'Imagerie Cellulaire Pitié Salpêtrière" supported by Inserm and UPMC. Dr Yong Wang is gratefully acknowledged for preparation of the cell imaging samples. Cell viability assays were performed at the CIBI platform of the ICSN (CNRS, Gif/Yvette, France).

\section{REFERENCES}

[1] B. Rosenberg, L. Van Camp, T. Krigas, Nature 1965, 205, 698-699.

[2] L. Kelland, Nat. Rev. Cancer 2007, 7, 573-584.

[3] N. P. E. Barry, P. J. Sadler, Chem. Commun. 2013, 49, 5106-5131.

[4] I. Ott, R. Gust, Arch. Pharm. (Weinheim) 2007, 340, 117-126.

[5] Y. K. Yan, M. Melchart, A. Habtemariam, P. J. Sadler, Chem. Commun. 2005, 4764-4776.

[6] Z. Liu, P. J. Sadler, Acc. Chem. Res. 2014, 47, 1174-1185.

[7] P. C. Bruijnincx, P. J. Sadler, Curr. Opin. Chem. Biol. 2008, 12, 197-206.

[8] T. Gianferrara, I. Bratsos, E. Alessio, Dalton Trans. 2009, 7588-7598.

[9] G. Gasser, I. Ott, N. Metzler-Nolte, J. Med. Chem. 2011, 54, 3-25.

[10] I. Romero-Canelón, P. J. Sadler, Inorg. Chem. 2013, 52, 12276-12291.

[11] M. Marloye, G. Berger, M. Gelbcke, F. Dufrasne, Future Med. Chem. 2016, 8, 2263-2286.

[12] G. Jaouen, M. Salmain, Bioorganometallic Chemistry: Applications in Drug Discovery, Biocatalysis, and Imaging, John Wiley \& Sons, 2015.

[13] Z. Liu, A. Habtemariam, A. M. Pizarro, S. A. Fletcher, A. Kisova, O. Vrana, L. Salassa, P. C. A. Bruijnincx, G. J. Clarkson, V. Brabec, et al., J. Med. Chem. 2011, 54, 3011-3026.

[14] Z. Liu, L. Salassa, A. Habtemariam, A. M. Pizarro, G. J. Clarkson, P. J. Sadler, Inorg. Chem. 2011, 50, 5777-5783.

[15] J. Yellol, S.A. Perez, A. Buceta, G. Yellol, A. Donaire, P. Szumlas, P.J. Bednarski, G. Makhloufi, C. Janiak, A. Espinosa, J. Ruiz, J. Med. Chem. 2015, 58, 7310-7327.

[16] Z. Liu, A. Habtemariam, A. M. Pizarro, G. J. Clarkson, P. J. Sadler, Organometallics 2011, 30, 4702-4710.

[17] V. Novohradsky, Z. Liu, M. Vojtiskova, P. J. Sadler, V. Brabec, J. Kasparkova, Metallomics 2014, 6, 682-690.

[18] A. J. Millett, A. Habtemariam, I. Romero-Canelón, G. J. Clarkson, P. J. Sadler, Organometallics 2015, 34, $2683-2694$.

[19] Z. Liu, I. Romero-Canelón, B. Qamar, J. M. Hearn, A. Habtemariam, N. P. E. Barry, A. M. Pizarro, G. J. Clarkson, P. J. Sadler, Angew. Chem. Int. Ed. 2014, 53, 3941-3946.

[20] Z. Liu, I. Romero-Canelón, A. Habtemariam, G. J. Clarkson, P. J. Sadler, Organometallics 2014, 33, 5324-5333.

[21] L. He, Y. Li, C-P. Tan, R-R. Ye, M-H. Chen, J-J. Cao, L-N. Ji, Z-W. Mao, Chem. Sci. 2015, 6, 5406-5418

[22] J-J. Cao, C-P. Tan, M-H. Chen, N. Wu, D-Y. Yao, X-G. Liu, L-N. Ji, Z-W. Mao, Chem. Sci. 2017, 8, 631-640.

[23] A. Wilbuer, D.H. Vlecken, D.J. Schmitz, K. Kräling, K. Harns, C.P. Bagowski, E. Meggers, Angew. Chem. Int. Ed. 2010, 49 , $3839-3842$.

[24] N. Boens, V. Leen, W. Dehaen, Chem. Soc. Rev. 2012, 41, 1130-1172.

[25] A. Loudet, K. Burgess, Chem. Rev. 2007, 107, 4891-4932.

[26] Y. V. Zatsikha, V. P. Yakubovskyi, M. P. Shandura, I. Y. Dubey, Y. P. Kovtun, Tetrahedron 2013, 69, 2233-2238.

[27] G. Ulrich, R. Ziessel, A. Harriman, Angew. Chem. Int. Ed. 2008, 47, 1184-1201.

[28] S. Zhang, T. Wu, J. Fan, Z. Li, N. Jiang, J. Wang, B. Dou, S. Sun, F. Song, X. Peng, Org. Biomol. Chem. 2012, 11, 555-558.

[29] T. Kowada, H. Maeda, K. Kikuchi, Chem. Soc. Rev. 2015, 44, 4953-4972.

[30] Q.-X. Zhou, W.-H. Lei, Y.-J. Hou, Y.-J. Chen, C. Li, B.-W. Zhang, X.-S. Wang, Dalton Trans. 2013, 42, $2786-2791$.

[31] T. Wang, Y. Hou, Y. Chen, K. Li, X. Cheng, Q. Zhou, X. Wang, Dalton Trans. 2015, 44, 12726-12734.

[32] T. Sun, X. Guan, M. Zheng, X. Jing, Z. Xie, ACS Med. Chem. Lett. 2015, 6, 430-433.

[33] J. C. Jagodinsky, A. Sulima, Y. Cao, J. E. Poprawski, B. N. Blackman, J. R. Lloyd, R. E. Swenson, M. M. Gottesman, M. D. Hall, JBIC J. Biol. Inorg. Chem. 2015, 20, 1081-1095.

[34] K. Mitra, S. Gautam, P. Kondaiah, A. R. Chakravarty, ChemMedChem 2016, 11, 1956-1967.

[35] P.-E. Doulain, R. Decréau, C. Racoeur, V. Goncalves, L. Dubrez, A. Bettaieb, P. L. Gendre, F. Denat, C. Paul, C. Goze, et al., Dalton Trans. 2015, 44, 4874-4883.

[36] J. Bartelmess, W. W. Weare, R. D. Sommer, Dalton Trans. 2013, 42, 14883-14891.

[37] S. Tasan, O. Zava, B. Bertrand, C. Bernhard, C. Goze, M. Picquet, P. L. Gendre, P. Harvey, F. Denat, A. Casini, et al., Dalton Trans. 2013, 42, 6102-6109.

[38] J. Bartelmess, W. W. Weare, Dyes Pigments 2013, 97, 1-8.

[39] G.-G. Luo, K. Fang, J.-H. Wu, J.-C. Dai, Q.-H. Zhao, Phys. Chem. Chem. Phys. 2014, 16, 23884-23894. 
[40] G. M. Chu, I. Fernández, A. Guerrero-Martínez, C. Ramírez de Arellano, M. A. Sierra, Eur. J. Inorg. Chem. 2016, $2016,844-852$.

[41] S. Betanzos-Lara, L. Salassa, A. Habtemariam, P. J. Sadler, Chem. Commun. 2009, 6622-6624.

[42] G. Jaouen, N. Metzler-Nolte, Eds., Medicinal Organometallic Chemistry, Springer Berlin Heidelberg, Berlin, Heidelberg, 2010.

[43] M. R. Reithofer, A. K. Bytzek, S. M. Valiahdi, C. R. Kowol, M. Groessl, C. G. Hartinger, M. A. Jakupec, M. Galanski, B. K. Keppler, J. Inorg. Biochem. 2011, 105, 46-51.

[44] D. J. Minick, J. H. Frenz, M. A. Patrick, D. A. Brent, J. Med. Chem. 1988, 31, 1923-1933.

[45] M. G. Pomper, H. VanBrocklin, A. M. Thieme, R. D. Thomas, D. O. Kiesewetter, K. E. Carlson, C. J. Mathias, M. J. Welch, J. A. Katzenellenbogen, J. Med. Chem. 1990, 33, 3143-3155.

[46] J. Schindelin, I. Arganda-Carreras, E. Frise, V. Kaynig, M. Longair, T. Pietzsch, S. Preibisch, C. Rueden, S. Saalfeld, B. Schmid, et al., Nat. Methods 2012, 9, 676-682. 